\begin{tabular}{lll}
\hline SINAI Journal of Applied Sciences & $\overline{\text { SCU-EGYPT }}$ \\
\hline SASS
\end{tabular}

\title{
EFFECT OF TWO TYPES OF PROTEACEOUS FOOD ON THE BEE VENOM PRODUCTIVITY
}

\author{
Mohamed A. H. ${ }^{1}$; M. N. El-Bassiony ${ }^{1}$; H. M. Mahfouz ${ }^{1}$ and A. M. Eid $^{2}$ \\ 1. Dept. of Plant Production, Faculty of Environ. Agri. Sc., El-Arish, Suez Canal Univ., Egypt. \\ 2. Dept. of Economic Entomology and Pesticides, Faculty of Agriculture, Cairo University, Egypt.
}

\begin{abstract}
This study was conducted to study the effects of some factors that could increase the productivity of honeybee venom. This investigation discusses improving the production of the venom from honey bees colonies by using the technique electrical impulses. This study includes several essential axes, Such as using types of different nutrition proteins which are mixed with $50 \%$ honeybee. When honey bee colonies contain sufficient areas from bee bread, the extraction by electrical impulses produced during 2011 (40.3 mg dry venom /colony). The quantity decreased to ( $29.87 \mathrm{mg}$ dry venom /colony) when honey bee deprived from bee bread. It means that scarcity of bee bread in honey bee colonies during period of venom collection reduced their productivity by (-34.78\%). Whereas, during $2012(29.38 \mathrm{mg}$ dry venom) when honey bee deprived from bee bread. The quantity increased to $(44.25 \mathrm{mg}$ dry venom) when honey bee colonies contain sufficient areas from bee bread. It means that scarcity of bee bread in honey bee colonies during period of venom collection reduced their productivity by $(-50.37 \%)$.
\end{abstract}

Key words: Honeybee, sting apparatus, bee venom, venom sac, acid gland, bee food.

\section{INTRODUCTION}

For several years ago, many investigations were conducted on honey bee products. These products are very important due to their pharmacological activity, which influence different biological and medical aspects.

Bee venom therapy is the part of apitherapy which utilizes bee venom in the treatment of health conditions.

Apitherapy is the use of bee hive products including, honey, pollen, propolis, royal jelly and bee venom. It has been used since ancient times and in this modern age as an alternative therapy to treat multiple components have been isolated and characterized, and their primary structures determined by biochemical techniques.

These compounds are responsible for many toxic or allergic reactions in different sclerosis, Lyme disease, and chronic fatigue syndrome. Bee venom is a rich source of enzymes, peptides and biogenic amines.

There are at least 18 active components in the venom (El-Bassiouny, 2007) this compound is a clear liquid with bitter taste, aromatic odour and acidic reaction.It dissolves completely in water. Bee venom contains a number of pharmacologically active polypeptides, chief among which are apamine, melittin and mast cell degranulating peptide (Shipolini, 1984).

Hymenoptera venoms are complex mixtures containing simple organic molecules, proteins, peptides, and other bioactive elements. Several of these organisms, such as local pain, inflammation, itching, irritation, and moderate or severe allergic reactions.

The most extensively characterized Hymenoptera venoms are bee venoms, 
mainly from the Apis genus and also from social wasps and ant species.

However, there is little information about other Hymenoptera groups. The Apis venom presents high molecular weight molecules - enzymes with a molecular weight higher than $10.0 \mathrm{k} \mathrm{Da}$ - and peptides.

The best studied enzymes are phospholipase A2, responsible for cleaving the membrane phospholipids, hyaluronidase, which degrades the matrix component hyaluronic acid into non-viscous segments and acid phosphatase acting on organic phosphates. The main peptide compounds of bee venom are lytic peptide melittin, apamin (neurotoxic), and mastocyte degranulating peptide (MCD) (De Lima and Brochetto-Braga, 2003).

\section{MATERIALS AND METHODS}

The experiment was carried out in the apiary of Faculty of Environmental Agricultural Sciences in El-Arish, Suez Canal University on the first hybrid Carniolan honey bee. during seasons of 2011/2012 in order to study two types of proteinaceous food affecting of amount of bee venom produced by honey bee workers and, the relation between bee venom amount and supplemental Mushroom powder cake as proteinaceous food in honey bee colony during Spring and Summer of 2011, 2012.

For these goals the following experiments were carried out. The main objective of the present work had been oriented to study improvement of bee venom quantity produced directly from honey bee colonies by electrical impulses techniques.

\section{Bee venom collection:}

The collection of the bee venom was made every 15 days or 30 days for 15 minutes by using the Impulses Technique Device.

Such device was put on bottom of the hives. 15 days or 30 days interval was chosen for venom collection to avoid deterioration of the experimental colonies under poor agricultural structure of the North Sinai flora and to give the opportunity to the colonies for reactivation.

The suitable day time for venom collection was selected between early mornings or on sun set to ensure the exposure of the most workers to the device. Such method may cause death to some bees, which were lost their stings.

For this purpose, 9 Colonies of the relatively similar strength were chosen which divided into three groups, each group considered three colonies, these three groups considered for one treatment.

\section{The main experiments:}

Effect of proteinaceous food on bee venom production during Spring and Summer of 2011, 2012:

Nine honeybee colonies from local hybrid carniolan bees equal in strength were selected and divided into three groups, each one consisted of three honey colony as follows:

\section{First group:}

Honey bee colonies were provided with access of honey bread areas (two frames) which were considered as sufficient protein food supply.

\section{Second group:}

Honey bee colonies free from bee bread frames and pollen traps were situated on the entrance of each hive to avoid the entry of pollen grains in it.

Dried Mushrooms were used with antioxidant in addition of vitamins. The Mushrooms were dried at $60^{\circ} \mathrm{C}$ in order to not broken the protein compounds and use it as alternative protein. $250 \mathrm{gm}$ was added weekly to every colony during experimental period.

\section{Third group:}

Honey bee colonies free from bee bread 
frames were provided by pollen traps situated on the entrance of each hive to avoid the presence of pollen grains in it. Beginning of collection the amount of dry bee venom within two years on the same way and the duration is the same period which used in all experiments (15 minutes) also collects venom after 15 days of treatment.

\section{Statically analysis}

Data was subjected to analysis of variance; t-test, f-test, for preparation and correlation, It was used to compared specific pairs of mean.

The randomized factorial design was used and date was subjected to analysis of variance. Separation of means among treatments was determined using L.S.D Sendecor and Cochran, (1972).

\section{RESULTS AND DISCUSSION}

Relation between bee venom amount and supplemental Mushroom powder cake as proteinaceous food in honey bee colony during spring and summer of 2011, 2012:

The amount of bee venom was extracted electrically for $15 \mathrm{~min}$. from the carniolan hybrid honey bee colonies in Al-Arish apiary after feeding them on two types of proteinaceous food, i.e., adequate amount of stored pollen grains (normal colony), cake of Mushroom powder and colonies free from proteinaceous food for comparison.

The data given in Tables (1) and (2) graphically illustrated in Figs 1 and 2 summarize the obtained results.

In 2011 the amount of dry bee venom extracted from the experimental colonies

Table (1): Amounts of bee venom extracted from honey bee colony on two types of proteinaceous food in Arish apiary during the summer season $0 \mathrm{fo11}$.

\begin{tabular}{lccccc}
\hline Types of proteinaceous food & \multicolumn{3}{c}{$\begin{array}{c}\text { Weight of dry venom } \\
\text { (mg/colony) }\end{array}$} & $\begin{array}{c}\text { Raring15 min. } \\
\text { or of increment (+) } \\
\text { ofecrement(-) from } \\
\text { pollen grain food }\end{array}$ \\
\cline { 2 - 4 } & Min. & Max. & Mean \pm S.E. & \\
\hline Free from proteinaceous food & 25.7 & 32.6 & $29.23 \pm 1.99^{\mathrm{c}}$ & -29.66 \\
Adequate stored pollen grains only & 33.1 & 43.1 & $37.90 \pm 2.89^{\mathrm{b}}$ & - \\
Cake of mushroom powder only & 46.3 & 52.8 & $46.83 \pm 2.82^{\mathrm{a}}$ & +24.1 \\
F. value & & & 2.35 & \\
L.S.D at $\mathbf{0 . 0 5}$ & & & 6.09 & \\
\hline
\end{tabular}

Figures between brackets represent the statistical sorting according to the L.S.D value.

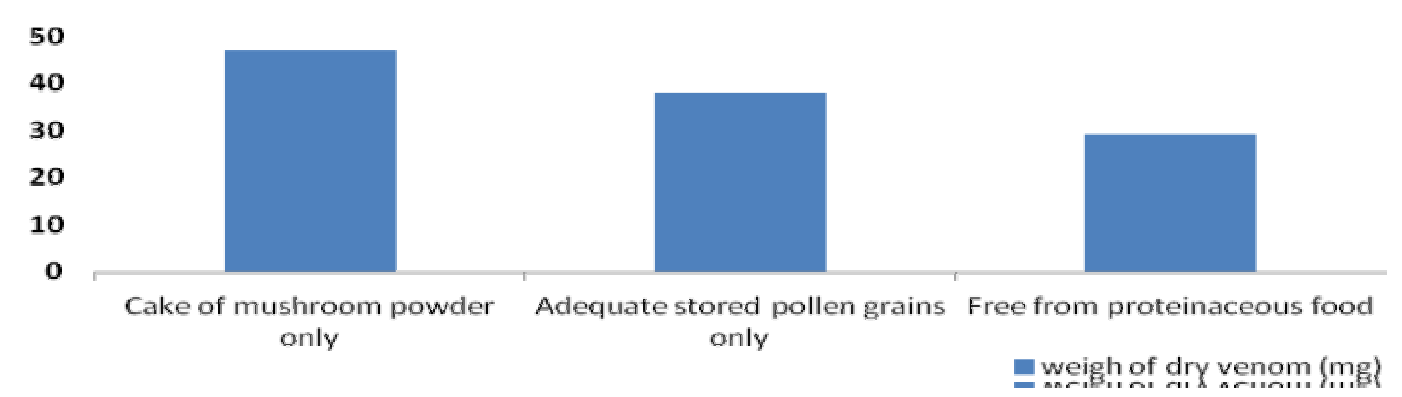

Fig. (1): Mean weight of dry bee venom (mg) extracted from honey bee colony during 15 min. after feeding on different proteinaceous food in summer season of 2011. 
varied according to the type of proteinaceous food offered them.

Adequate amount of stored pollen grains caused normal amount of extracted dry bee venom, being $37.90 \mathrm{mg} /$ colony.

However, using the mushroom powder in form of cake as proteinaceous food obviously increased the extracted dry bee venom $49.37 \mathrm{mg} /$ colony and the different between both means proved to be statistically highly significantly.

In case of honey bee colonies, which did not supply with proteinaceous food, the lowest amount of dry bee venom was obtained $29.23 \mathrm{mg} /$ colony (Table 1 and Fig.1). The data clearly show that after using mushroom powder cake the amount of dry bee venom increased by $24.10 \%$ as compared with that of venom produced from colonies fed on pollen grain only, while it decreased by $29.66 \%$ in colonies free from proteinaceous food. The statistical analysis of the data showed highly significant different between these means and the L.S.D value 6.09 $\mathrm{mg} /$ colony emphasize the obtained result.

In the available literature, honey bee workers used protein of pollen mainly to provide structural elements of muscles, glands and other tissues.

Under normal condition, pollen consumption diminishes when the bees are of 8 to 10 days old (Dietz, 1975).The stored pollen areas in excited honey bee colonies by electrical impulses for venom production decreased. These results can be explained that stressed bees by electrical impulses consumed more protein for developing venom glands (Omar, 1994b).

The data given in Table (2) and graphically illustrated in Fig. (2) shows that in spring of 2012, the Adequate amount of stored pollen grains in the honey bee colonies produced normal amount of extracted dry bee venom being $49.37 \mathrm{mg} /$ colony on electrical device for $15 \mathrm{~min}$. While replacing the pollen grains by cake of mushroom powder as

Table (2): Amounts of bee venom extracted from honey bee colony on two types of proteinaceous food in Arish apiary during the Spring season of 2012.

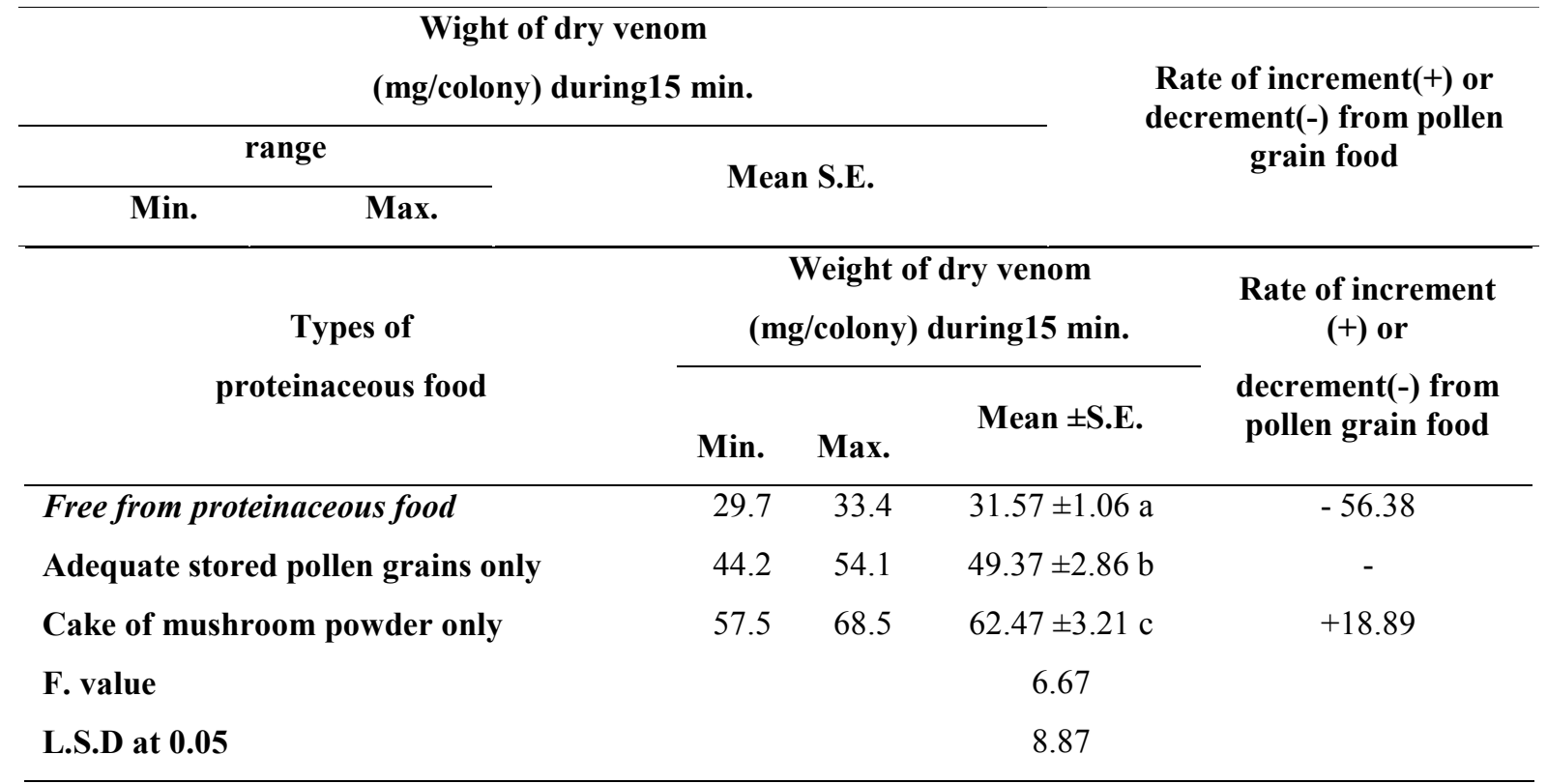

Mean weight of dry bee venom ( $\mathrm{mg}$ ) extracted from honey bee colony during $15 \mathrm{~min}$. after feeding on different proteinaceous food in spring season of 2012. 


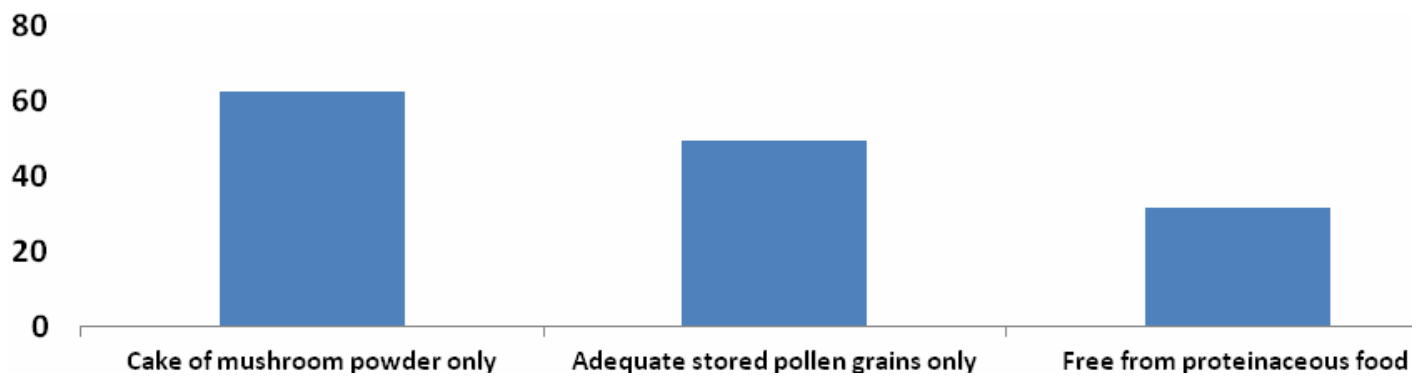

Fig. (2): Figures between brackets represent the statistical sorting according to the L.S.D value.

proteinaceous food significantly increased the production ofcake of mushroom powder as proteinaceous food significantly increased the production of dry bee venom to be 62.47 $\mathrm{mg} /$ colony.

In case of honey bee colonies free from proteinaceous food, the least amount of dry bee venom 31.57 colonies produced the highest amount of dry bee venom by $18.89 \%$ as compared with $\mathrm{mg}$ /colony was obtained.

The later amount was relatively similar to that obtained in 2011.

Using cake of mushroom powder for bee such amount of venom obtained from colonies fed on pollen grains, which decreased by $56.38 \%$ in colonies lack proteinaceous food.

The statistical analysis of the data showed highly significant different between these means and the L.S.D value $8.87 \mathrm{mg} /$ colony

emphasize the obtained result. In their study on the efficacy of feeding protein substitutes to honey bee found slightly poorer development of honey bee glands against that fed bee bread.

Also, Hanna and Schmidt (2004) reported that the biotic effect of different pollen substitutes was poor in comparison with bee bead stored in honey bee colonies (Szymas and PrzybyI 1996).

The results showed that scarcity bee venom in honey bee colonies during the period extraction reduce venom production by 50.3\% (Omar, 2011).

\section{REFERENCES}

De lima, P. R. and Borchetto, M. R., (2003). Hymenoptera venom review focusing on Apis mellifera., J. Venom Anim. Toxins, Vol. 9, No. 2. Dietz, A. C. (1975). Nutrition of the audit honey bee in the HamiIton, 111,p. 125.156.

EI-Bassiouny, A.M. (2007). Monitoring the reproductive individual in the oriental hornet Vespa orientalis. Arab Univ. J. Sci., 15 (2): 459-511. Omar, E.M.O (2011). Some factors affecting acid glands and honey bee venom productivity. M.Sc. Thesis, Assiut University .J. Agric. Sci., 89 pp.

Omar, M. O. M. (1994b). Some factors affecting bee venom extraction from honey bee colonies. Assiut. J. Agric Sci., 25:139-148.

Shipolini, R. A. (1984). Biochemistry of bee venom, hand book of Natural Toxins, Vol. 2, Marcel Dekkerin in C.N.Y, pp. $49-85$.

Snedecor, G. W. Cochran, W.G. (1972). Statistical method 6 .The Lowa State University press, Ames, Lowa USA. 59p.

Szymas, B. and A. Przybyl (1996). Physiological condition of worker bees Apis mellifera L. after consumption of pollensubstation Pszczaln Nauk. 40 (2): 109-117. 


\section{الملخص العربي \\ تأثير نوعين من الغذاء البروتيني على إنتاجية سم النحل}

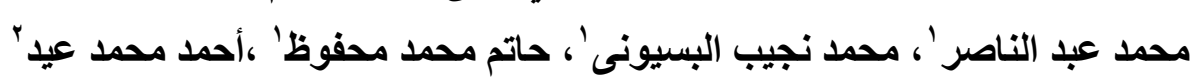

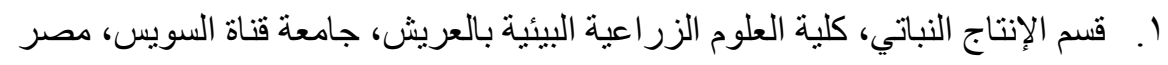

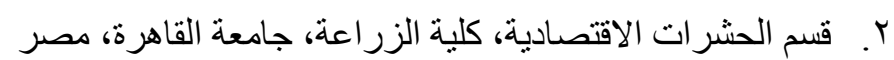

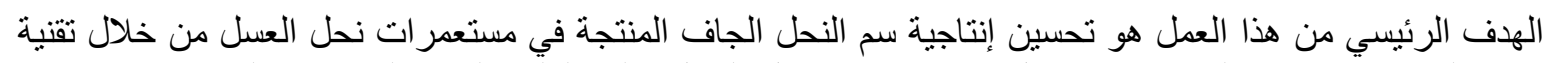

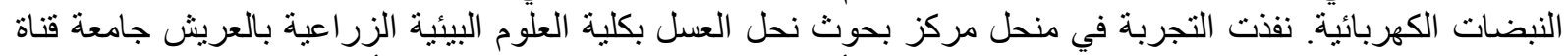





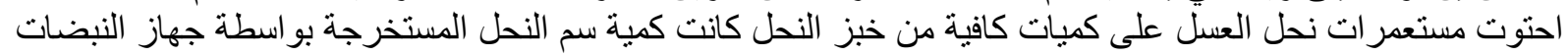

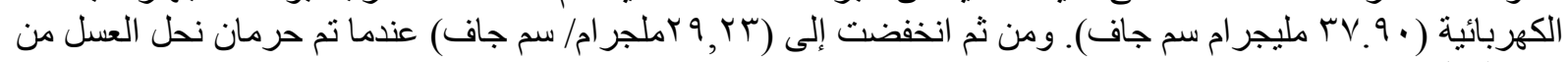
خبز النحل.

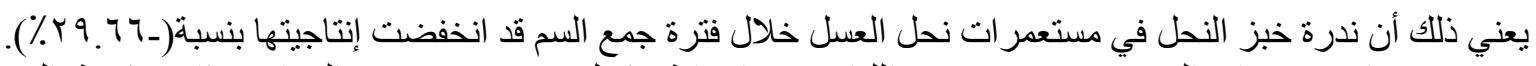

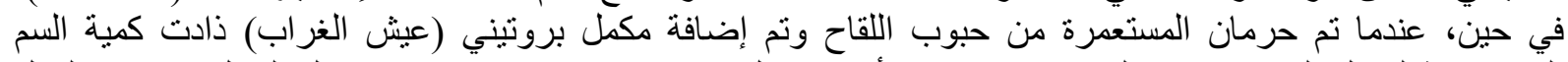

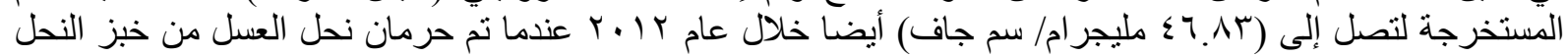

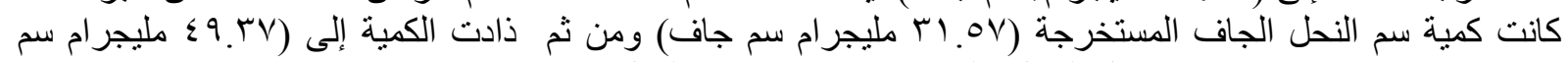
جاف) عندما احتوت مستعمر ات نحل العسل على كمية كافية من خبز النحل.

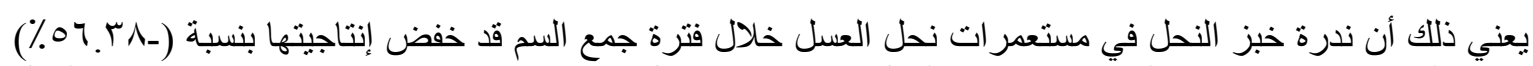

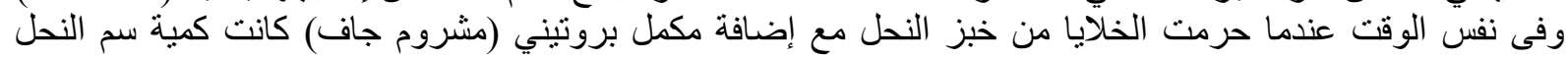

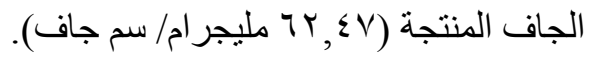
الكلمات الاسترشادية: نحل العسل، سم النحل، الغذاء البروتيني، خبز النحل.

أستاذ الحشرات الاقتصادية - كلية العلوم الزر اعبة البيئية بالعريش - جامعة قناة السويس- مصر

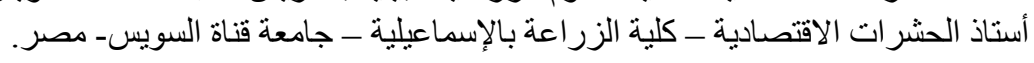

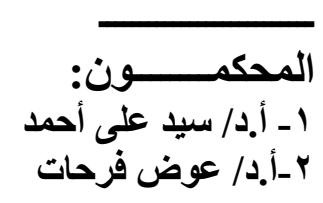

